\title{
Preceding crops influence agronomic efficiency in sugar beet cultivation
}

\author{
Anna Jacobs ${ }^{1,2}$ (I) $\cdot$ Heinz-Josef Koch ${ }^{1} \cdot$ Bernward Märländer ${ }^{1}$ \\ Accepted: 13 October 2017 / Published online: 27 December 2017 \\ (C) INRA and Springer-Verlag France SAS 2017
}

\begin{abstract}
The choice of the crop succession influences the agronomic efficiency (yield per unit agronomic input) and is relevant for the sustainable intensification of crop cultivation. However, such effects are often ignored in assessments of agronomic efficiency. The aim of the study was to propose a concept for the assessment of and to publish data on (i) the effect of the preceding crop on the amount of agronomic inputs used and the yield in sugar beet cultivation and (ii) the agronomic efficiency of the 2-year sum of preceding crop - sugar beet successions. As preceding crop (including catch crop) - sugar beet successions, we investigated (i) mustard - silage maize - sugar beet, (ii) phacelia - grain pea - mustard - sugar beet, and (iii) winter wheat - mustard - sugar beet in a field trial (Harste, Germany; 2011-2014). We found that fertilizer requirement of sugar beet was highest (108 $\mathrm{kg}$ nitrogen $\mathrm{ha}^{-1} ; 125 \mathrm{~kg}$ phosphate $\mathrm{ha}^{-1}$ ) when mustard - silage maize was the preceding crop and lowest (30 kg nitrogen ha ${ }^{-1} ; 96 \mathrm{~kg}$ phosphate $\mathrm{ha}^{-1}$ ) when phacelia - grain pea - mustard was the preceding crop. The efficiency of the agronomic inputs used for the cultivation of the 2-year sum of preceding crop - sugar beet successions was generally highest for the succession with silage maize with the exception of nitrogen-efficiency which was highest for the succession with grain pea. The main effect of the preceding crop on fertilizer requirement was driven by the amount of harvest residues. Results of 2-year agronomic efficiency were affected by the high energy yield of the succession with silage maize $\left(670 \mathrm{GJ} \mathrm{ha}^{-1}\right)$ and the low $\mathrm{N}$-fertilization in the succession with grain pea $\left(130 \mathrm{~kg} \mathrm{~N} \mathrm{ha}^{-1}\right)$. We show for the first time a methodological approach to assess preceding crop's effects on agronomic efficiency and to illustrate results for decision making towards a sustainable intensification of crop cultivation.
\end{abstract}

Keywords Sustainable intensification $\cdot$ Energy $\cdot$ Management $\cdot$ Crop rotation $\cdot$ Field experiment $\cdot$ Yield

\section{Introduction}

A worldwide challenge often described for the sustainable intensification of arable crop cultivation is the possible trade-off between increasing the yield of food, feed, and fiber without further aggravating environmental impacts (Tilman et al. 2002; Sattler et al. 2010). Within this challenge, decision

Anna Jacobs

anna.jacobs@thuenen.de

Heinz-Josef Koch

koch@ifz-goettingen.de

Bernward Märländer

maerlaender@ifz-goettingen.de

1 Institute of Sugar Beet Research, Holtenser Landstrasse 77, 37079 Goettingen, Germany

2 Present address: Thünen Institute, Institute of Climate-Smart Agriculture, Bundesallee 50, 38116 Braunschweig, Germany makers are caught between two choices when it comes to the use of agronomic inputs during crop cultivation; as one example, $\mathrm{N}$-fertilizer secures a stable and high yield on the one hand but, on the other hand, it provokes environmental impacts, such as eutrophication and global warming. The key to achieve the best possible equilibration is a high agronomic efficiency which is defined here as the relation of yield per unit of agronomic inputs used. Thus, agronomic efficiency plays a strong role as a parameter of "sustainable intensification." However, for decision makers and stakeholders in the field of agricultural practice (farming, consulting, legislation), it is difficult to quantify the agronomic efficiency due to its multidimensionality where various agronomic inputs have different responsibilities for yield performance and different environmental impacts (eutrophication, toxicity, global warming, and depletion of resources). Thus, straightforward tools to compare the agronomic efficiency of different crops and different options of cultivation management in a holistic assessment (Castoldi and Bechini 2010; Davis et al. 2013) are needed. 
To reach the greatest agronomic efficiency possible, the farmer needs to choose an adequate cultivation management in order to equilibrate the yield and the use of agronomic inputs (Franzluebbers and Francis 1995). Among others, the choice of crop successions within the crop rotation can influence the yield as well as the nutrient and physical status of the soil, the need of fertilizers, and the number of tillage passes (Dias et al. 2015; Franzluebbers and Francis 1995; Köpke and Nemecek 2010; Safa and Samarasinghe 2012). In short, the choice of crop succession determines the agronomic efficiency. Although it is known that a preceding crop can influence the agronomic efficiency of the subsequent crop, such effects are rarely or not investigated in, e.g., foot printing or life cycle assessments (Nemecek and Erzinger 2005; Köpke and Nemecek 2010). Moreover, it is regularly ignored that a preceding crop leaving a high amount of nutrients in the soil as harvest residues might strengthen the fertilization efficiency of the subsequent crop. We are convinced that sustainable intensification of crop cultivation must happen for the entire crop succession rather than for single crops. Thus, respective evaluations must also equalize different lengths of cultivation periods of crops and crop successions as a calculation basis in order to deliver non-biased comparisons.

Sugar beet (Beta vulgaris L.) is not self-compatible and needs to be cultivated in crop rotations, classically with cereals. Prices and socio-political claims currently diversify sugar beet's crop rotation partners. To the best of our knowledge, it was neither assessed how the choice of the preceding crop influences the use of agronomic inputs in sugar beet cultivation nor were the preceding crops themselves evaluated in succession with the subsequent sugar beet. Within our study, we focus on cultivation systems of sugar beet and aimed to assess (i) the effect of the preceding crop on the amount of agronomic inputs used in and on the yield of sugar beet cultivation and (ii) the agronomic efficiency of different 2-year long succession of "preceding crop - sugar beet". We thereby provide field trial data and propose a holistic concept for the multidimensional assessment of agronomic efficiency of preceding crop - crop successions.

\section{Materials and methods}

\subsection{Field trial}

We evaluated the years 2011-2014 of a crop rotation trial in Harste (51 $61^{\prime}$ N, $9^{\circ} 86^{\prime}$ E; Lower Saxony, Germany) (Fig. 1). All crop rotation elements were cultivated each year on a separate plot $\left(230 \mathrm{~m}^{2}\right)$ in three field replicates. Crop rotations with sugar beet were:

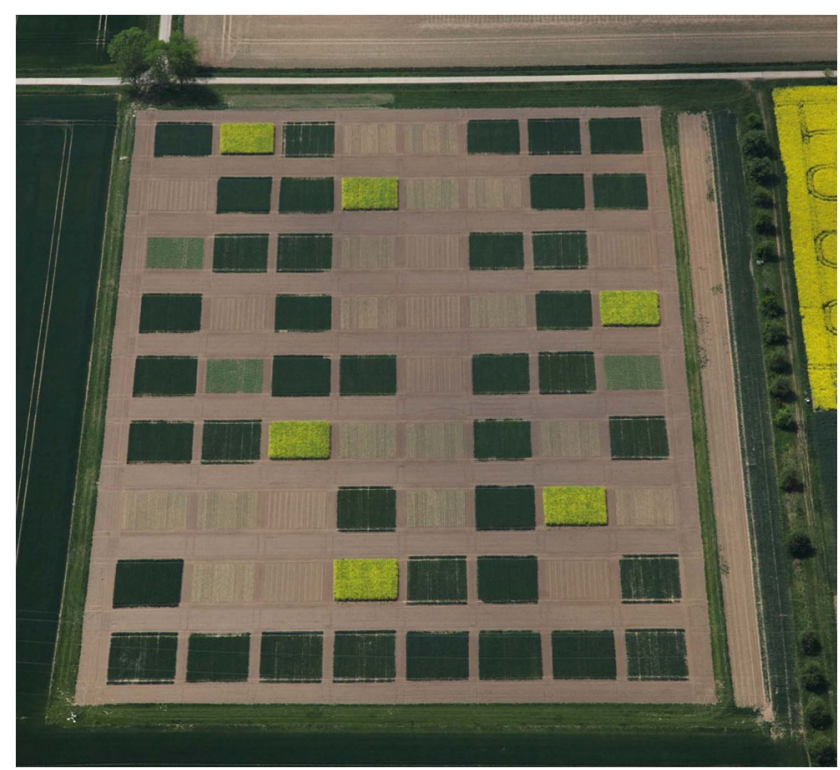

Fig. 1 The crop rotation trial in Harste, Lower Saxony, Germany. Since 2006, 24 crop rotation elements of currently nine crop rotations are cultivated in three field replicates. This study evaluates preceding crop effects on agronomic efficiency of sugar beet cultivation. Photo taken by Andreas Krukemeyer, May 2011

(i) winter wheat (Triticum aestivum L.) - mustard (Sinapis alba L.; catch crop) - silage maize (Zea mays L.) - sugar beet,

(ii) winter wheat - oilseed rape (Brassica napus L.) - winter wheat - winter wheat - phacelia (Phacelia Juss.; catch crop) - grain pea (Pisum sativum L.) - mustard (catch crop) - sugar beet, and

(iii) winter wheat - winter wheat - mustard (catch crop) sugar beet.

Our study focusses on sugar beet cultivation, and we therefore analyzed take-outs of these crop rotations of 2-year long successions of preceding crop (including catch crop cultivation) and sugar beet. We thereby compared sugar beet in a 3year rotation (i and iii) with sugar beet in a 6-year rotation (ii). However, we assumed that this fact does not bias our results since it was shown that an extension of the sugar beet interval within the crop rotation (years between sugar beet cultivation) to more than 3 years had a very slight effect on sugar beet yield (Götze et al. 2017). Moreover, Hao et al. (2001) showed a clear effect of the directly preceding crop on sugar beet yield. Thus, we assumed the preceding crop effects as predominant under our conditions and analyzed the following take-outs of the crop rotations:

(i) mustard - silage maize - sugar beet (mid of August to mid of September),

(ii) phacelia - grain pea - mustard - sugar beet (mid of August to mid of September), and 
(iii) winter wheat - mustard - sugar beet (end of September to mid of September).

This approach enabled to compare equal timeframes. For the following, we define "preceding crop" here as including the catch crops. Soil type was a Luvisol and the site was classified as "highly productive" under rainfed conditions in Central Europe (Brauer-Siebrecht et al. 2016). Tillage was done with a cultivator $(15-25 \mathrm{~cm}$ depth), and crop residues as well as catch crop biomass remained in the field for soil protection purposes.

\subsection{Agronomic inputs used and yield}

Agronomic inputs considered were the amounts of mineral Nand phosphorous $(\mathrm{P})$ fertilizers, of active ingredients in pesticides sprayed as well as the energy use as documented for each crop rotation element and each year of the field trial (Table 1). In detail, $\mathrm{N}$-fertilization was done according to the local recommendation of a mineral- $\mathrm{N}$ target value and the mineral-N content in the soil measured in spring (Landwirtschaftskammer Niedersachsen - Geschäftsbereich Landwirtschaft 2010). Phosphorous fertilization was modeled as the phosphate $\left(\mathrm{P}_{2} \mathrm{O}_{5}\right)$-need of each crop minus the redelivery via harvest residues of the respective preceding crop following the local recommendation of Baumgärtel (2013) and based on a measurement of soil nutrient status in 2010 (for values, see Brauer-Siebrecht et al. 2016). Pesticides were sprayed according to local recommendations. Energy use via production and application (diesel) of the agronomic inputs was considered to be of fossil sources and was aggregated among five categories: $\mathrm{N}$-fertilizer, $\mathrm{P}-/ \mathrm{K}-/ \mathrm{Mg}-/ \mathrm{B}-$ fertilizer, pesticides, diesel, and seeds. Energy equivalents, complementary assumptions, and further details are described in Jacobs et al. (2016).

Dry matter yield was determined for all crop rotation elements in each year in a subplot. Subplot size depended on machinery available and was $21 \mathrm{~m}^{2}$ for silage maize, $10.8 \mathrm{~m}^{2}$ for sugar beet, and $16.8 \mathrm{~m}^{2}$ for winter wheat and grain pea. Although the production goals of the different crops and also possibly for one crop are different (bioethanol, biogas, feed, sugar, starch, protein), the yield needed to be expressed in one unit which was the energy yield (Table 1). Therefore, the dry matter yield was multiplied with a default energy content of each crop. The energy content chosen was to stand for the nutritional value of the crops commonly reached under cultivation conditions in Germany: silage maize $18.07 \mathrm{GJ} \mathrm{t}^{-1}$ (Deutsche Landwirtschafts-Gesellschaft 1991), sugar beet root: $15.99 \mathrm{GJ} \mathrm{t}^{-1}$ (Deutsche Landwirtschafts-Gesellschaft 1991), winter wheat grain: $15.70 \mathrm{GJ} \mathrm{t}^{-1}$ (Feldheim et al. 1983), and grain pea: $18.75 \mathrm{GJ} \mathrm{t}^{-1}$ (LandwirtschaftsGesellschaft 1991).

\subsection{Calculations and statistics}

The efficiency of each agronomic input was expressed as the energy yield related to the amount of agronomic inputs used. Thereby, the sum of energy yield and agronomic inputs of the 2 -year preceding crop - sugar beet succession was taken. Land use efficiency was equal to the energy yield. To visualize the multidimensional agronomic efficiency, a spider graph was designed; the efficiencies of the individual agronomic inputs were not weighted assuming that they have equal importance for the overall agronomic efficiency (de Vries et al.

Table 1 Use of agronomic inputs (nitrogen, phosphorous, pesticide, energy) for the cultivation of different 2-year preceding crop - sugar beet successions and respective yield in a field trial in Harste (Germany, 2011-2014). Mean of years and standard deviation in parentheses $(n=4)$

\begin{tabular}{|c|c|c|c|c|c|c|c|c|c|c|}
\hline & \multicolumn{2}{|c|}{ Nitrogen $\left[\mathrm{kg} \mathrm{N} \mathrm{ha}{ }^{-1}\right]$} & \multicolumn{2}{|c|}{$\begin{array}{l}\text { Phosphorous }\left[\mathrm{kg} \mathrm{P}_{2} \mathrm{O}_{5}\right. \\
\left.\mathrm{ha}^{-1}\right]\end{array}$} & \multicolumn{2}{|c|}{$\begin{array}{l}\text { Pesticides [ } \mathrm{kg} \text { active } \\
\text { ingredient } \mathrm{ha}^{-1} \text { ] }\end{array}$} & \multicolumn{2}{|c|}{ Energy use [GJ ha $\left.{ }^{-1}\right]$} & \multicolumn{2}{|c|}{ Energy yield [GJ ha $\left.{ }^{-1}\right]$} \\
\hline & $\begin{array}{l}\text { Preceding } \\
\text { crop + catch } \\
\text { crop* }\end{array}$ & $\begin{array}{l}\text { Sugar } \\
\text { beet }\end{array}$ & $\begin{array}{l}\text { Preceding } \\
\text { crop + catch } \\
\text { crop }\end{array}$ & $\begin{array}{l}\text { Sugar } \\
\text { beet }\end{array}$ & $\begin{array}{l}\text { Preceding } \\
\text { crop + catch } \\
\text { crop }\end{array}$ & $\begin{array}{l}\text { Sugar } \\
\text { beet }\end{array}$ & $\begin{array}{l}\text { Preceding } \\
\text { crop + catch } \\
\text { crop }\end{array}$ & Sugar beet & $\begin{array}{l}\text { Preceding } \\
\text { crop }\end{array}$ & $\begin{array}{l}\text { Sugar } \\
\text { beet }\end{array}$ \\
\hline $\begin{array}{l}\text { Mustard - silage } \\
\text { maize - sugar } \\
\text { beet }\end{array}$ & $163(6)$ & $108(15)^{\mathrm{a}}$ & $436(3)$ & $125(0)^{\#}$ & $1.5(0.7)$ & $4.4(0.3)^{\mathrm{ns}}$ & $22.1(0.8)$ & $22.4(0.9)^{\mathrm{a}}$ & $383(46)$ & $287(37)^{\mathrm{ns}}$ \\
\hline $\begin{array}{l}\text { Phacelia - grain pea } \\
\text { - mustard - } \\
\text { sugar beet }\end{array}$ & $100(0)$ & $30(35)^{\mathrm{b}}$ & $283(8)$ & $96(8)$ & $3.1(0.2)$ & $4.6(0.6)$ & $14.7(0.2)$ & $17.2(1.5)^{\mathrm{c}}$ & $116(46)$ & $303(15)$ \\
\hline $\begin{array}{l}\text { Winter wheat - } \\
\text { mustard - sugar } \\
\text { beet }\end{array}$ & $266(9)$ & $75(13)^{\mathrm{ab}}$ & $260(2)$ & $99(4)$ & $4.9(0.6)$ & $4.6(0.6)$ & $21.8(0.5)$ & $19.6(0.8)^{\mathrm{b}}$ & $131(24)$ & $289(16)$ \\
\hline
\end{tabular}

Different letters indicate significant differences in sugar beet cultivation after different preceding crops (Tukey $p \leq 0.05$ ); $n s$ non-significant

*Catch crops were mustard and phacelia

\# Use of phosphorous for sugar beet cultivation was not statistically evaluated because it was constant when cultivated after mustard - silage maize over years investigated 
2010). Further, for each agronomic input, the most efficient 2year preceding crop - sugar beet succession was set to 1 , and the other successions were related to it (de Vries et al. 2010).

For the energy yield of crops, the mean value of field replicates per year was calculated. For the agronomic inputs, field replicates were not applicable. Thus, for statistics, the years were the independent replications $(n=4)$. Analysis of variance was conducted to test the influence of the fixed factor "preceding crop - sugar beet" on the efficiency of agronomic inputs. Tukey's test was performed to compare mean values. The level of significance was $\alpha=5 \%$. Tests were carried out with SAS 9.3 (SAS Institute Inc., Cary, USA) using the procedure "mixed".

\section{Results and discussion}

\subsection{Use of agronomic inputs and yield of sugar beet cultivated in different preceding crop - sugar beet successions}

We showed that, except for the use of pesticides, the choice of the preceding crop (including catch crop) determines the use of agronomic inputs in sugar beet cultivation (Table 1). The local recommendation for fertilizer use in sugar beet cultivation were (i) $160 \mathrm{~kg} \mathrm{~N} \mathrm{ha}^{-1}$, with a reduction recommended of $20 \mathrm{~kg} \mathrm{~N} \mathrm{ha}^{-1}$ when a catch crop was cultivated the autumn before sugar beet, minus the mineral- $\mathrm{N}$ content measured in spring and (ii) $85 \mathrm{~kg} \mathrm{P}_{2} \mathrm{O}_{5} \mathrm{~kg} \mathrm{ha}^{-1}$ with additional $40 \mathrm{~kg} \mathrm{P}_{2} \mathrm{O}_{5}$ $\mathrm{kg} \mathrm{ha}^{-1}$ due to the high yield achieved at this site (Baumgärtel 2013). Generally, the use of mineral fertilizer for sugar beet was highest when cultivated after mustard - silage maize $\left(108 \mathrm{~kg} \mathrm{~N} \mathrm{ha}^{-1} ; 125 \mathrm{~kg} \mathrm{P}_{2} \mathrm{O}_{5} \mathrm{ha}^{-1}\right)$ and lowest when cultivated after phacelia - grain pea - mustard $\left(30 \mathrm{~kg} \mathrm{~N} \mathrm{ha}^{-1} ; 96 \mathrm{~kg} \mathrm{P}_{2} \mathrm{O}_{5}\right.$ $\mathrm{ha}^{-1}$ ) with a significant difference between both mean values for the amount of $\mathrm{N}$. This was due to the very low amount of harvest residues left in the field after silage maize harvest which forces high amounts of fertilizer for the subsequent sugar beet (Baumgärtel 2013). In contrast, the amount of Nfertilizer needed for sugar beet cultivation was lowest in the phacelia - grain pea - mustard succession. Grain pea as a legume has the advantage of symbiotic $\mathrm{N}$-fixation and does not need any $\mathrm{N}$-fertilization at all (Nemecek et al. 2008). The $100 \mathrm{~kg} \mathrm{~N} \mathrm{ha}^{-1}$ indicated were for the catch crops phacelia and mustard. Moreover, after phacelia - grain pea - mustard cultivation, high amounts of mineral-N in the soil were measured in spring before sugar beet planting (mean of years and field replicates in $0-90 \mathrm{~cm}: 100 \mathrm{~kg} \mathrm{ha}^{-1}$ in contrast to $55 \mathrm{~kg} \mathrm{ha}^{-1}$ after mustard - silage maize and $70 \mathrm{~kg} \mathrm{ha}^{-1}$ after winter wheat - mustard; data not shown) which led to a considerable reduction of the $\mathrm{N}$ needed as mineral fertilizer for sugar beet.

In contrast, the amount of pesticide use in sugar beet cultivation was not driven by the preceding crop (including catch crop) - sugar beet succession and was 4.4-4.6 kg active ingredient per hectare (Table 1). The effects shown were mirrored in the parameter "energy use" since it also included the energy needed for the production of fertilizers; the energy used for sugar beet cultivation was significantly higher when cultivated after mustard - silage maize $\left(22.4 \mathrm{GJ} \mathrm{ha}^{-1}\right)$ and lowest when cultivated after phacelia - grain pea - mustard $\left(17.2 \mathrm{GJ} \mathrm{ha}^{-1}\right)$. Among mineral fertilizers, N-production is very energy intensive (Biograce 2013; Brentrup and Pallière 2008), and thus, sugar beet cultivated after phacelia - grain pea - mustard needed the lowest energy use as well.

The agronomic inputs can be attributed to multiple environmental impacts: (i) a proportion of $1.3 \%$ of the mineral-N fertilized is suggested by default (de Klein et al. 2006) to be emitted as nitrous oxide which is of a high global warming potential (IPCC 2014; Köpke and Nemecek 2010). (ii) Phosphorous is a non-renewable resource which is depleted via usage as fertilizer (Van Vuuren et al. 2010). (iii) Further, the higher the amount of $\mathrm{N}$ and $\mathrm{P}$ used as fertilizers, the higher the risk of emission into water bodies and, thus, the risk of aquatic eutrophication (Sattler et al. 2010; Van Vuuren et al. 2010). (iv) The amount of pesticides used indicates the risk of toxicity in aquatic and terrestrial compartments (Lal 2004). (v) The use of energy needed for crop cultivation mirrors the burning of fossil energy resources and the respective global warming potential. Thus, the preceding crop (including catch crop) phacelia - grain pea - mustard in our study had the main advantage to reduce global warming potential and risk of eutrophication due to sugar beet cultivation.

Across the years investigated, the mean energy yield of sugar beet was somewhat, but not significantly, higher after phacelia - grain pea - mustard cultivation than after the other preceding crops, ranging from 287 to $303 \mathrm{GJ} \mathrm{ha}^{-1}$ (Table 1). We found that the year 2014 was the only year when sugar beet cultivated after phacelia - grain pea - mustard did not give the highest yield (data not shown).

\subsection{Agronomic efficiency of 2-year preceding crop - sugar beet successions}

A high amount of agronomic inputs used can be appropriate when yield achieved is also high. Thus, the agronomic efficiency was defined as the energy yield related to the amount of agronomic inputs used for crop cultivation. Moreover, we calculated it as the respective sums of the 2-year preceding crop - sugar beet successions in order to avoid allocation mistakes. As a further efficiency parameter, we defined the land use efficiency and considered the natural resource "land" as a valuable agronomic inputs.

Significantly lowest in N-efficiency was the 2-year succession winter wheat - mustard - sugar beet $\left(1.2 \mathrm{GJ} \mathrm{kg}^{-1}\right)$ compared to both other successions (mustard - silage maize sugar beet $2.5 \mathrm{GJ} \mathrm{kg}^{-1}$; phacelia - grain pea - mustard - sugar 
beet 3.4 GJ kg${ }^{-1}$ ) (Table 2). Phosphorous efficiency did not differ statistically between successions $\left(2.5-2.9 \mathrm{GJ} \mathrm{kg}^{-1}\right)$. Pesticide efficiency of the succession mustard - silage maize - sugar beet was by far and significantly highest $\left(115 \mathrm{GJ} \mathrm{kg}^{-1}\right.$ ) compared to both other successions (phacelia - grain pea mustard - sugar beet $54 \mathrm{GJ} \mathrm{kg}^{-1}$; winter wheat - mustard sugar beet $44 \mathrm{GJ} \mathrm{kg}^{-1}$ ). Energy efficiency was as well highest for the succession mustard - silage maize - sugar beet (10.1 GJ GJ ${ }^{-1}$ ) but not significantly different from the one with grain pea $\left(9.0 \mathrm{GJ} \mathrm{GJ}^{-1}\right)$. The succession with winter wheat was significantly lowest in energy efficiency $\left(6.7 \mathrm{GJ} \mathrm{GJ}^{-1}\right)$. In land use efficiency, the succession mustard - silage maize - sugar beet was significantly highest $\left(670 \mathrm{GJ} \mathrm{ha}^{-1}\right.$ ) compared to both other successions (winter wheat - mustard - sugar beet $420 \mathrm{GJ} \mathrm{ha}^{-1}$; phacelia - grain pea - mustard - sugar beet $419 \mathrm{GJ} \mathrm{ha}^{-1}$ ).

The multidimensional spider graph of agronomic efficiency (Fig. 2) gave evidence that the 2-year succession mustard silage maize - sugar beet generally had the greatest agronomic efficiency since this succession needed the largest amount of agronomic inputs, except for pesticides, but gave the by far highest energy yield (Table 1, Table 2). The exception was Nefficiency where the phacelia - grain pea - mustard - sugar beet succession performed best (Table 2) due to the very low amount of N-fertilizer used (Table 1).

Franzluebbers and Francis (1995) and Nemecek et al. (2008) reported as well that integrating legumes into the rotation can increase $\mathrm{N}$ - and energy efficiency of the entire succession or crop rotation. Even though $\mathrm{N}$-inputs are low, Nemecek et al. (2008) pointed out that legumes can increase the risk of N-leaching of crop rotations when mineral Ncontents in the soil are high during periods of low N-need by plants. In our field trial, we might have reduced the risk of N-leaching via cultivation of mustard as a catch crop between grain pea and sugar beet. However, to provide equal conditions across successions, this mustard was fertilized with $50 \mathrm{~kg} \mathrm{~N}^{-1}$ (Table 1). Abolishment of using mineral fertilizer on catch crops, especially after legume cultivation but also in terms of implementing the recent EU-regulation on common agriculture policy (also known as "greening"; European Union 2013), would further increase the Nefficiency of crop rotations. The winter wheat - mustard sugar beet succession showed the lowest agronomic efficiency (Fig. 2, Table 2) due to high amounts of agronomic inputs used and lowest yield (Table 1). Although cereals are the classic crop rotation partners for sugar beet, our study showed that they are unfavorable in terms of agronomic efficiency. However, one must not forget the nutritional value of cereal cultivation as grains for bread baking and feed. This aspect clearly shows the limits of studies like ours since social or traditional values, which are not measurable, are not respected. A further high value of cereals in a crop rotation is the high amount of straw which, when left in the field after harvest, strongly contributes to a positive humus balance (Götze et al. 2016). Anyway, for a complete assessment of sustainability, further effects on environmental compartments, economy, and society are to be considered. However, in our study, we focused on factors farmers usually consider in the course of crop rotation design. One of such factors is the phytosanitary effect of a preceding crop; maize is, as sugar beet, a host for the fungus Rhizoctonia solani (relevant subgroup: AG2-2 IIIB) and can promote a possible infection of the subsequent sugar beet (Buhre et al. 2009). Although different legumes were as well reported to be hosts of $R$. solani AG2-2 IIIB, pea was, so far, not (Sneh et al. 1996). However, during our field trial, no $R$. solani infection on sugar beet was observed (data not shown).

Generally, when farmers aim to increase yield, they usually apply higher amounts of agronomic inputs, e.g., fertilizer. However, when yield increases proportionally leading to a stable or raised agronomic efficiency, any change in cultivation management is a contribution to sustainable intensification of crop cultivation. Vice versa, a reduction of agronomic inputs must not decrease the yield. Thereby, the interaction among the different agronomic inputs needs to be considered, e.g., when herbicide spraying is replaced by mechanical hoeing which increases diesel (energy) consumption. This interaction is visualized by the multidimensional spider graph we
Table 2 Efficiency of the use of agronomic inputs (energy yield per unit nitrogen, phosphorous, pesticide, energy, and land) for the cultivation of different 2-year preceding crop - sugar beet successions in a field trial in Harste (Germany, 2011-2014). Mean of years and standard deviation in parentheses $(n=4)$. Catch crop cultivation (mustard, phacelia) was included

\begin{tabular}{|c|c|c|c|c|c|}
\hline Succession & $\begin{array}{l}\text { Nitrogen } \\
\text { efficiency [GJ } \\
\left.(\mathrm{kg} \mathrm{N})^{-1}\right]\end{array}$ & $\begin{array}{l}\text { Phosphorous } \\
\text { efficiency [GJ } \\
\left.\left(\mathrm{kg} \mathrm{P}_{2} \mathrm{O}_{5}\right)^{-1}\right]\end{array}$ & $\begin{array}{l}\text { Pesticide efficiency } \\
\text { [GJ (kg active } \\
\text { ingredient })^{-1} \text { ] }\end{array}$ & $\begin{array}{l}\text { Energy } \\
\text { efficiency } \\
{\left[G J G J^{-1}\right]}\end{array}$ & $\begin{array}{l}\text { Land use } \\
\text { efficiency } \\
{\left[\mathrm{GJ} \mathrm{ha}^{-1}\right]}\end{array}$ \\
\hline $\begin{array}{l}\text { Mustard - silage } \\
\text { maize - sugar } \\
\text { beet }\end{array}$ & $2.5(0.4)^{\mathrm{a}}$ & $2.9(0.3)^{\mathrm{ns}}$ & $115(13)^{\mathrm{a}}$ & $10.1(1.2)^{\mathrm{a}}$ & $670(73)^{\mathrm{a}}$ \\
\hline $\begin{array}{l}\text { Phacelia - grain } \\
\text { pea - mustard } \\
\text { - sugar beet }\end{array}$ & $3.4(0.9)^{\mathrm{a}}$ & $2.5(0.3)$ & $54(4)^{b}$ & $9.0(0.9)^{\mathrm{a}}$ & $419(49)^{b}$ \\
\hline $\begin{array}{l}\text { Winter wheat - } \\
\text { mustard - } \\
\text { sugar beet }\end{array}$ & $1.2(0.1)^{\mathrm{b}}$ & $2.6(0.3)$ & $44(5)^{\mathrm{b}}$ & $6.7(0.6)^{\mathrm{b}}$ & $420(34)^{b}$ \\
\hline
\end{tabular}

Different letters indicate significant differences between successions (Tukey, $\mathrm{p} \leq 0.05$ ); ns: non-significant 
Fig. 2 Multidimensional agronomic efficiency (energy yield per unit nitrogen, phosphorous, pesticide, energy, and land) of different 2-year preceding crop - sugar beet successions in a field trial in Harste (Germany, 2011-2014). Mean of years $(n=4)$. Catch crop cultivation (mustard, phacelia) was included. The succession with the greatest efficiency of the respective indicators was equal to 1

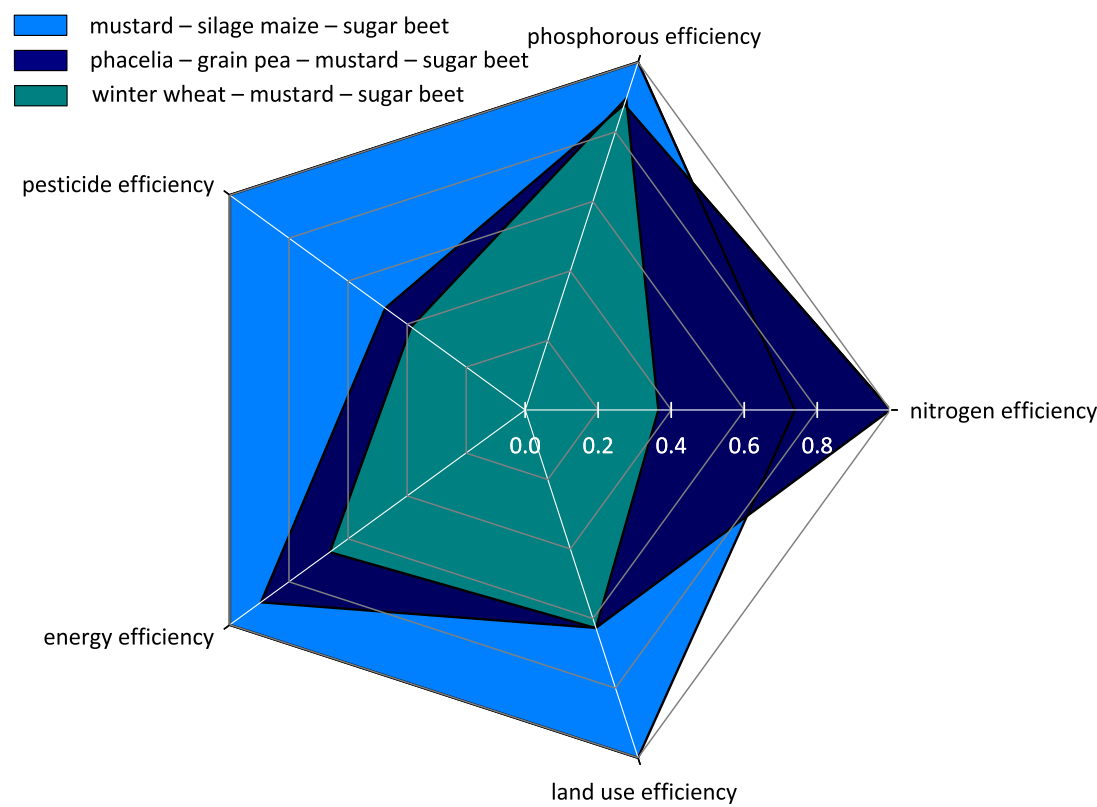

provided (Fig. 2). Moreover, the spider graph compares the agronomic efficiency of different preceding crop - crop (here: sugar beet) successions and facilitates decision making and communication. In our study, the efficiencies of the different agronomic inputs were not weighted in terms of the severity of their environmental impacts. Although such a weighting plus an aggregation of indicators into one single index might facilitate the interpretation, it depends on personal opinions or policy intentions which are usually not transparent (Castoldi and Bechini 2010; Nardo et al. 2008). Further, we suggest that the compensation of a weak efficiency of one agronomic means by a high efficiency of another means, as assumed when aggregating indicators into one single index (Castoldi and Bechini 2010; Nardo et al. 2008), is not reasonable. We thereby refer to the concept of "strong sustainability" of Dietz and Neumayer (2007) where the depletion of natural resources, as energy or $\mathrm{P}$, is generally irreversible. The visualization presented in this study enables an individual decision in accordance with the actual circumstances and aims. Overall, we showed that effects of the preceding crop need to be accounted for when the agronomic efficiency is evaluated, and we provided a respective methodological approach.

\section{Conclusions}

Overall, we provided an assessment based on reliable field trial's data which supports the development of default values and concepts for the assessment of the agronomic efficiency of crop successions. Our study closes a gap in assessment concepts for a development towards sustainable intensification of crop cultivation. We concluded that the choice of the preceding crop, including catch crop cultivation, determines the amount of agronomic inputs used in sugar beet cultivation. However, the main driver for the agronomic efficiency of 2year preceding crop - sugar beet successions was the preceding crop itself with differences in the need of agronomic inputs and in yield performance. We thus suggest to consider either high yielding (e.g., silage maize) or low input (e.g., legumes) preceding crops in future choices of crop successions.

Acknowledgements Parts of this study were done with support from Federal Ministry of Food and Agriculture by decision of the German Bundestag and via the Fachagentur Nachwachsende Rohstoffe e. V. within the joint project "The sugar beet as an energy crop in crop rotations on highly productive sites - an agronomic/economic system analysis". We are grateful for technical help especially for the conduction of the field trials and to further support in data assessing. Thus, "Thank you!" to Jens Günther, Marten Steinke and their team, Wiebke Brauer-Siebrecht, Friederike Hoberg, and Ronja Ruppelt. We further thank the anonymous reviewers for their helpful comments to our manuscript.

\section{References}

Baumgärtel G (2013) Düngung. In: Landwirtschaftskammer Niedersachsen (ed) Empfehlungen 2013 - Pflanzenbau und Pflanzenschutz. Albrecht Druck, Hannover, pp 6-21

BioGrace (2013) List of Standard Values - Version 4 - Public. http:// www.biograce.net/content/ghgcalculationtools/recognisedtool/. Accessed 15 Janurary 2013

Brauer-Siebrecht W, Jacobs A, Christen O, Götze P, Koch H-J, Rücknagel J, Märländer B (2016) Silage maize and sugar beet for biogas production in rotations and continuous cultivation: dry matter and estimated methane yield. Agron 6:2. https://doi.org/10.3390/ agronomy 6010002

Brentrup F, Pallière C (2008) GHG Emissions and Energy Efficiency in European Nitrogen Fertiliser Production and Use. In: The International Fertiliser Society (ed) Proceedings 639 - Conference in Cambridge on 11th December 2008, pp 1-26 
Buhre C, Kluth C, Bürcky K, Märländer B, Varrelmann M (2009) Integrated control of root and crown rot in sugar beet: combined effects of cultivar, crop rotation, and soil tillage. Plant Dis 93:155 161. https://doi.org/10.1094/PDIS-93-2-0155

Castoldi N, Bechini L (2010) Integrated sustainability assessment of cropping systems with agro-ecological and economic indicators in northern Italy. Eur J Agron 32:59-72. https://doi.org/10.1016/j.eja. 2009.02.003

Davis SC, Boddey RM, Alves BJR, Cowie AL, George BH, Ogle SM, Smith P, van Noordwijk M, van Wijk MT (2013) Management swing potential for bioenergy crops. Glob Chang Biol Bioenergy 5:623-638. https://doi.org/10.1111/gcbb.12042/full

de Klein C, Novoa RSA, Ogle S, Smith KA, Rochette P, Wirth TC, McConkey BG, Mosier A, Rypdal K, Walsh M, Williams SA (2006) N2O emissions from managed soils, and $\mathrm{CO} 2$ emissions from lime and urea application. In: National Greenhouse Gas Inventories Programme, Eggleston HS, Buendia L, Miwa K, Ngara T, Tanabe K (ed) 2006 IPCC Guidelines for National Greenhouse Gas Inventories. IGES Hayama, Kanagawa, pp 11.111.54

de Vries SC, van de Ven GWJ, van Ittersum MK, Giller KE (2010) Resource use efficiency and environmental performance of nine major biofuel crops, processed by first-generation conversion techniques. Biomass Bioenergy 34:588-601. https://doi.org/10.1016/j. biombioe.2010.01.001

Deutsche Landwirtschafts-Gesellschaft (1991) DLG-Futterwerttabellen für Wiederkäuer. DLG-Verlag, Frankfurt

Dias T, Dukes A, Antunes PM (2015) Accounting for soil biotic effects on soil health and crop productivity in the design of crop rotations. J Sci Food Agric 95:447-454. https://doi.org/10.1002/jsfa.6565

Dietz S, Neumayer E (2007) Weak and strong sustainability in the SEEA: concepts and measurement. Ecol Econ 61:617-626. https://doi.org/ 10.1016/j.ecolecon.2006.09.007

European Union (2013) Regulation (EU) No 1307/2013 of the European Parliament and of the Council of 17 december 2013 establishing rules for direct payments to farmers under support schemes within the framework of the common agricultural policy and repealing Council Regulation (EC) No 637/2008 and Council Regulation (EC) No 73/2009. http://eur-lex.europa.eu/legal-content/EN/TXT/ PDF/?uri=CELEX:32013R1307\&from=en. Accessed 09 June 2016

Feldheim W, Wisker E, Augustin S (1983) Brennwert und Ballaststoffgehalt von Getreideflocken, Mehlen und Broten. Z Lebensm Unters Forsch 176:183-189. https://doi.org/10.1007/ BF01417825

Franzluebbers AJ, Francis CA (1995) Energy output:input ratio of maize and sorghum management systems in eastern Nebraska. Agric Ecosyst Environ 53:271-278. https://doi.org/10.1016/01678809(94)00568-Y

Götze P, Rücknagel J, Jacobs A, Märländer B, Koch H-J, Holzweißig B, Steinz M, Christen O (2016) Sugar beet rotation effects on soil organic matter and calculated humus balance in Central Germany. Eur J Agron 76:198-207. https://doi.org/10.1016/j.eja.2015.12.004
Götze P, Rücknagel J, Wensch-Dorendorf M, Märländer B, Christen O (2017) Crop rotation effects on yield, technological quality and yield stability of sugar beet after 45 trial years. Eur J Agron 82:50-59. https://doi.org/10.1016/j.eja.2016.10.003

Hao X, Chang C, Conner RL, Bergen P (2001) Effect of minimum tillage and crop sequence on crop yield and quality under irrigation in a southern Albert clay loam soil. Soil Till Res 59:45-55. https://doi. org/10.1016/S0167-1987(00)00185-9

IPCC (2014) Climate Change 2014: Synthesis Report. In: Core Writing Team, Pachauri PK, Meyer LA (ed). Contribution of Working Groups I, II and III to the Fifth Assessment Report of the Intergovernmental Panel on Climate Change. IPCC, Geneva

Jacobs A, Brauer-Siebrecht W, Rücknagel J, Götze P, Christen O, Koch H-J, Märländer B (2016) Silage maize and sugar beet for biogas production in crop rotations and continuous cultivation - energy efficiency and land demand. Field Crops Res 196:75-84. https:// doi.org/10.1016/j.fcr.2016.06.008

Köpke U, Nemecek T (2010) Ecological services of faba bean. Field Crops Res 115:217-233. https://doi.org/10.1016/j.fcr.2009.10.012

Lal R (2004) Carbon emission from farm operations. Environ Int 30:981990. https://doi.org/10.1016/j.envint.2004.03.005

Landwirtschaftskammer Niedersachsen - Geschäftsbereich Landwirtschaft (2010) Empfehlungen zur Stickstoffdüngung nach der $\mathrm{N}_{\min }$-Methode. http://www.lwk-niedersachsen.de/index.cfm/ portal/pflanze/nav/341/article/14022.html. Accessed 13 May 2016

Nardo M, Saisana M, Saltelli A, Tarantola S, Hoffmann A, Giovannini E (2008) Handbook on Constructing Composite Indicators Methodology and User Guide. http://www.oecd.org/std/42495745. pdf. Accessed 09 May 2016

Nemecek T, Erzinger S (2005) Modelling representative life cycle inventories for Swiss arable crops. Int J LCA 10:68-76. https://doi.org/10. 1065/lca2004.09.181.8

Nemecek T, von Richthofen J-S, Dubois G, Casta P, Charles R, Pahl H (2008) Environmental impacts of introducing grain legumes into European crop rotations. Eur J Agron 28:380-393. https://doi.org/ 10.1016/j.eja.2007.11.004

Safa M, Samarasinghe S (2012) $\mathrm{CO}_{2}$ emissions from farm inputs "case study of wheat production in Canterbury, New Zealand". Environ Pollut 171:126-132. https://doi.org/10.1016/j.envpol.2012.07.032

Sattler C, Nagel UJ, Werner A, Zander P (2010) Integrated assessment of agricultural production practices to enhance sustainable development in agricultural landscapes. Ecol Indic 10:49-61. https://doi. org/10.1016/j.ecolind.2009.02.014

Sneh B, Jabaji-Hare S, Neate S, Dijst G (eds) (1996) Rhizoctonia species: taxonomy, molecular biology, ecology, pathology and disease control. Kluwer Academic Publishers, Dordrecht

Tilman D, Cassman KG, Matson PA, Naylor R, Polasky S (2002) Agricultural sustainability and intensive production practices. Nature 418:671-677. https://doi.org/10.1038/nature01014

Van Vuuren DP, Bouwman AF, Beusen AHW (2010) Phosphorus demand for the 1970-2100 period: a scenario analysis of resource depletion. Glob Environ Chang 20:428-439. https://doi.org/10. 1016/j.gloenvcha.2010.04.004 